\title{
PHYSICO-CHEMICAL AND SURFACE CHARACTERISATION OF A RENEWABLE LOW-COST BIOSORBENT FOR THE UPTAKE OF HEAVY METAL IONS FROM AQUEOUS SOLUTION
}

\author{
JOHN O. ODIYO \& JOSHUA N. EDOKPAYI \\ Department of Hydrology and Water Resources, University of Venda, South Africa
}

\begin{abstract}
The persistence and toxicity of heavy metals in the environment is of global concern. Powdered biomass from the stem of Diceriocaryum eriocarpum plant (DEP) was characterised and applied as a possible biosorbent for the uptake of $\mathrm{Pb}(\mathrm{II}), \mathrm{Cu}(\mathrm{II})$ and $\mathrm{Cr}(\mathrm{VI})$ from aqueous solution. The bulk density and moisture content of DEP stem were found to be $0.7026 \mathrm{~g} / \mathrm{mL}$ and $5.36 \%$, respectively. Thermogravimetric analysis showed the stability of the biosorbent up to $200^{\circ} \mathrm{C}$. Results from scanning electron microscopy (SEM) showed a flasky and crack filled surface morphology. The BrunauerEmmett Teller (BET) isotherm gave a total surface area of $2.5052 \mathrm{~m}^{2} / \mathrm{g}$. XRF analysis revealed the presence of calcium as the major element present. Experimental data from Fourier-Transform Infra-red spectrometer indicated the presence of hydroxyl, carbonyl, amino and nitro functional groups. The biosorbent showed $95.4 \%, 54.9 \%$ and $16.3 \%$ uptake efficiencies for $\mathrm{Pb}(\mathrm{II}), \mathrm{Cr}(\mathrm{VI})$ and $\mathrm{Cu}(\mathrm{II})$, respectively. Kinetic data for the biosorption of $\mathrm{Pb}$ (II) gave a Pseudo-second order as the best fitting kinetic model. The equilibrium data obtained best fitted into the Freundlich isotherm model $(R=0.99)$ than the Langmuir $(\mathrm{R}=0.98)$ model. Powdered stem from DEP is a suitable biosorbent for the uptake of heavy metals from aqueous solution.

Keywords: biosorbent, bulk density, DEP, environment, Freundlich, heavy metals, kinetics, Langmuir, remediation, wastewater.
\end{abstract}

\section{INTRODUCTION}

Inadequate supply of potable water is a global problem which is exacerbated particularly in developing countries of the world. Reliance on surface water has been a welcome alternative due to population growth and increased industrialisation [1], [2]. The quality of surface water has declined as it serves as the best sink for several industrial and domestic wastes [3], [4]. Research into wastewater management has largely focused on heavy metals due to their deleterious effects and persistence once released to the environment [5], [6]. Several short and long-term effects on humans and the aquatic ecosystems are well documented [6]-[10].

The toxicity and persistence of heavy metals in various environmental media still remains a major cause of challenge despite decades of research into it [11], [12]. US EPA published 13 metals which include: $\mathrm{Ag}, \mathrm{As}, \mathrm{Be}, \mathrm{Cd}, \mathrm{Cr}, \mathrm{Cu}, \mathrm{Hg}, \mathrm{Ni}, \mathrm{Pb}, \mathrm{Sb}, \mathrm{Se}, \mathrm{Tl}$ and $\mathrm{Zn}$ as priority pollutants due to their adverse effects on plants, aquatic organisms and on human health [13], [14]. Several physiological disorders in humans and other biological systems have been linked to the consumption of metal rich water. Adequate preventive mechanisms must be put in place to deter the introduction of such metals accumulation into the environment and human food chain [12]. National and international authorities have set guidelines and threshold limits for the monitoring of these contaminants due to the health hazards brought by their presence in water and other environmental media.

The use of low-cost renewable biosorbents are preferred to the costly conventional methods and are currently undergoing rigorous research by scientists owing to their ability to sequester heavy metals at trace levels. Dicerocaryum Eriocarpum plant (DEP) is a 
perennial (sometimes annual), prostrate herb with long trailing stems (about $3.5 \mathrm{~m}$ long) that usually scramble over the ground. It is commonly found in Southern African countries on grasslands, dune slopes and river banks of high elevation (900-1200 m) [15]-[16]. This paper presents the characterisation and potential use of a renewable, low cost and environmental friendly material for the uptake of heavy metals from aqueous solutions.

\section{MATERIALS AND METHODS}

\subsection{Preparation of the biosorbent}

The plant samples were randomly collected from grasslands in Siloam village, Limpopo Province, South Africa. Identification of the plant as Dicerocaryum eriocarpum species of the Pedaliaceae family was done by botanists from Botany Department, University of Venda [17]. The plant was washed with tap water, sun dried for a day and oven dried at $105^{\circ} \mathrm{C}$ for 18 hours. After drying, other parts of the plant such as the leaves and root were detached from it while the stem was ground with a hammer mill and fractionated using analytical sieves. Particle size of $<150 \mu \mathrm{m}$ was chosen for all the various experiments.

\subsection{Reagents}

All the reagents used were of analytical grade. Merck (pty) Limited in Johannesburg, South Africa supplied the Hydrochloric acid (32\%), sodium hydroxide and $1000 \mathrm{mg} / \mathrm{L}$ stock solution of $\mathrm{Pb}(\mathrm{II}), \mathrm{Cu}(\mathrm{II})$ and $\mathrm{Cr}(\mathrm{VI})$ used in the various experiments of this study.

\subsection{Determination of bulk density, moisture content and mass of loss on ignition}

The bulk density and moisture content were determined using the method reported by Moyo and Chikazaza [18]. Briefly, sufficient quantity of the biosorbent was transferred into a 10 $\mathrm{mL}$ measuring cylinder of $1.0 \mathrm{~cm}$ diameter. The bulk density was obtained by the relation in eqn (1) and was expressed in grams per milliliter.

$$
\text { Bulk density }(\mathrm{g} / \mathrm{mL})=\frac{W_{b}}{V_{C}},
$$

where $\mathrm{W}_{\mathrm{b}}$ is the weight of biosorbent filling $10 \mathrm{~mL}$ measuring cylinder on gentle tapping, $\mathrm{V}_{\mathrm{c}}$ is the volume of the cylinder.

$10 \mathrm{~g}$ of the biosorbent was put inside oven at $105^{\circ} \mathrm{C}$ in order to obtain the moisture content. After 6 hours, it was removed and cooled in a desiccator to prevent re-absorption of atmospheric moisture. The percentage moisture content was calculated using eqn (2),

$$
\% \text { moisture content }=\frac{\left(W_{2}-W_{3}\right) \times 100}{\left(W_{2}-W_{1}\right)},
$$

where $W_{1}$ is the weight of empty crucible, $W_{2}$ is the initial weight of the crucible with the sample, $W_{3}$ is the final weight of the crucible with the sample.

The loss of mass on ignition was performed by accurately weighing $12 \mathrm{~g}$ of the biosorbent into a porcelain crucible and putting it inside a furnace at a constant temperature of $600^{\circ} \mathrm{C}$ for 2 hours. The charred biosorbent was removed and placed in a desiccator for cooling. The difference in mass of the original and charred sample represents the mass loss on ignition.

\subsection{Instrumentation}

X-ray florescence measurement was carried out using Rigaku, ZSX Primus II X-ray Fluorescence spectrometer. Fourier transform infrared (FT-IR) spectrometer supplied by 
Perkin Elmer was employed to identity the functional groups that are present on the biosorbent. Before analysis, a mixture of biosorbent and powdered $\mathrm{KBr}$ was mixed in ratio 1:20 and the mixture were pelletised [17]. Surface morphology was determined using a scanning electron microscopy (SEM). The surface area was analysed using a surface area analyzer (Micromeritics Chemisorption ASAP 2020 supplied by Norcross, USA). The thermal stability of the biosorbent was performed using a Perkin Elmer thermal analyzer (Waltham, Ma, 02451, USA) [17].

\subsection{Biosorption studies}

Batch experiments of the biosorption process were carried out in $100 \mathrm{~mL}$ polyethylene bottle with caps. Varying amount of the stock solution was added into the containers to achieve the desired concentrations. The desired $\mathrm{pH}$ of the solution was obtained by adjusting it using 0.1 $\mathrm{M} \mathrm{HCl}$ and $\mathrm{NaOH}$, respectively. Biosorbent dosage is an important parameter in any biosorption experiment as it gives a clue to the quantity of the biosorbent to be used in order to obtain an efficient uptake of the target pollutant. Initially, $1.0 \mathrm{~g}$ of the biosorbent was added to $10.7 \mathrm{mg} / \mathrm{L}$ of initial $\mathrm{Pb}(\mathrm{II}), \mathrm{Cu}(\mathrm{II})$ and $\mathrm{Cr}(\mathrm{VI})$ solutions at a $\mathrm{pH}$ of 6.0 , shaking speed of $250 \mathrm{rpm}$ and time $=60$ minutes. The result showed uptake efficiencies of $95.5 \%, 54.9 \%$ and $16.3 \%$ for $\mathrm{Pb}(\mathrm{II}), \mathrm{Cu}(\mathrm{II})$ and $\mathrm{Cr}(\mathrm{VI})$, respectively. $\mathrm{Pb}(\mathrm{II})$ was chosen for subsequent biosorption studies because the biosorbent had a greater affinity for it than the other metals investigated. Different quantities of the biosorbent in the range of $0.01-2.0 \mathrm{~g}$ were added to $10.7 \mathrm{mg} / \mathrm{L}$ of initial $\mathrm{Pb}^{2+}$ under the same experimental condition (shaking speed of $250 \mathrm{rpm}$ and time $=60$ minutes). The optimum dosage was obtained and used for subsequent experiments.

$\mathrm{pH}$ plays an important role in the biosorption of metals to the surface of a biosorbent. Some metals are better adsorbed at low $\mathrm{pH}$ values while others at high $\mathrm{pH}$ and a few shows independences from the $\mathrm{pH}$ of the solution. A $\mathrm{pH}$ range of 2-14 was investigated in this experiment, while other operating parameters were kept constant. The effect of initial concentration of $\mathrm{Pb}^{2+}$ was investigated by varying the $\mathrm{Pb}$ concentrations from $1-50 \mathrm{mg} / \mathrm{L}$.

Kinetic experiments were performed by mixing $1.0 \mathrm{~g}$ of the biosorbent to $40 \mathrm{~mL}$ of 10.7 $\mathrm{mg} / \mathrm{L}$ of $\mathrm{Pb}^{2+}$ solution at $298 \mathrm{~K}$ in a $100-\mathrm{mL}$ polyethylene bottle. The mixtures were then equilibrated for 60 minutes using a Stuart reciprocal mechanical shaker at $250 \mathrm{rpm}$ at different time intervals. Atomic Absorption spectrophotometer supplied by Perkin Elmer was used to analyse the concentrations of heavy metals prior and after the biosorption process. The biosorption capacity was calculated by using the relation in eqn (3)

$$
q_{e}=\left(C_{o}-C_{e}\right) V / M
$$

where $q_{e}$ is the biosorption capacity in $\mathrm{mg} / \mathrm{g}, C_{o}$ and $C_{e}$ are the initial and equilibrium concentration of lead(II) ion in $\mathrm{mg} / \mathrm{L}$. $\mathrm{V}$ is the volume of the solution in litres and $\mathrm{M}$ is the weight of powdered stem of DEP in grams.

\section{RESULTS AND DISCUSSION}

\subsection{Surface characteristics of the biosorbent}

Fig. 1 shows the SEM micrograph of the biosorbent. The presence of a flasky structure was observed from the SEM micrograph. The XRF analysis shows that the major element present in the stem of DEP is calcium (27.8\%) followed by potassium (16.5\%) (Table 1). A Brunaeur- 


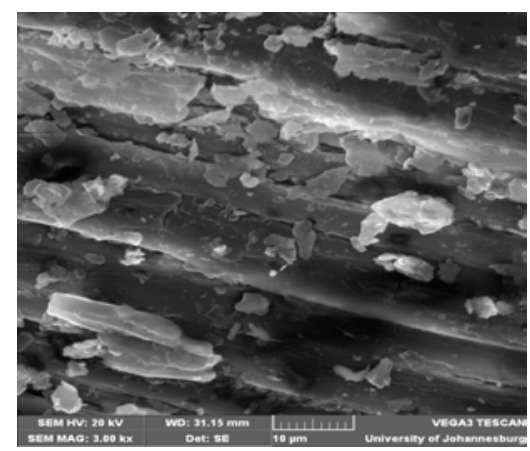

Figure 1: Surface morphology of the biosorbent.

Table 1: Chemical analysis of the biosorbent.

\begin{tabular}{cc}
\hline Component & \% weight composition \\
\hline $\mathrm{Na}_{2} \mathrm{O}$ & 5.92 \\
$\mathrm{MgO}$ & 10.5 \\
$\mathrm{Al}_{2} \mathrm{O}_{3}$ & 2.55 \\
$\mathrm{SiO}_{2}$ & 7.02 \\
$\mathrm{SO}_{3}$ & 11.5 \\
$\mathrm{Cl}$ & 2.98 \\
$\mathrm{~K}_{2} \mathrm{O}$ & 16.5 \\
$\mathrm{CaO}$ & 27.8 \\
$\mathrm{Fe}_{2} \mathrm{O}_{3}$ & 6.07 \\
$\mathrm{BaO}$ & 2.29 \\
\hline
\end{tabular}

Emmett Teller (BET) surface area of $2.5052 \mathrm{~m} / \mathrm{g}$ was obtained (Table 2) which is the range of BET values reported for other biosorbents in literature such as mucilaginous leaves of Dicerocaryum eriocarpum, macadamia and maize tassels with BET surface areas of $1.8517 \mathrm{~m}^{2} / \mathrm{g}$ [17], $1.083 \mathrm{~m} / \mathrm{g}$ [19] and $2.52 \mathrm{~m} / \mathrm{g}$ [20], respectively. Surface area of an adsorbent usually plays a major role in adsorption experiments; generally, the larger the surface area the greater the adsorption capacity [21]. The adsorption capacity of avocado kernel seed increased when the surface area was increased by activation and carbonisation [21]. The results obtained for the bulk density and moisture contents are also presented in Table 2.

\subsection{Thermal stability of the biosorbent}

Thermogravimetric analysis (TGA) is used to characterise the thermal stability and decomposition of materials that occur over specific temperature ranges. Result of the TGA curve obtained is shown in Fig. 2. $8.7 \mathrm{mg}$ of the dried powdered stem of DEP was heated between $30-900^{\circ} \mathrm{C}$ at a rate of $10^{\circ} \mathrm{C} \mathrm{min}^{-1}$ using a TGA analyzer supplied by Perkin Elmer. Initially, between $30^{\circ} \mathrm{C}$ and $150^{\circ} \mathrm{C}$ the biosorbent seems to be stable with a very slight loss in weight, which could be attributed to the loss of water molecules and other volatile low molecular weight substances. A sharp increase in degradation was observed between $214^{\circ} \mathrm{C}$ and $390^{\circ} \mathrm{C}$ and this corresponds to $55.2 \%$ loss in the initial weight of the biosorbent. After 
Table 2: Physicochemical characteristics of the biosorbent.

\begin{tabular}{|c|c|}
\hline Parameter & Value \\
\hline $\mathrm{pH}$ & 5.93 \\
\hline Moisture content $(\%)$ & 5.36 \\
\hline Loss of mass on ignition (\%) & 90 \\
\hline Bulk density $(\mathrm{g} / \mathrm{mL})$ & 0.7026 \\
\hline BET surface area $\left(\mathrm{m}^{2} / \mathrm{g}\right)$ & 2.5052 \\
\hline Pore volume $\mathrm{P} / \mathrm{P}_{\mathrm{o}}=0.995\left(\mathrm{~cm}^{3} / \mathrm{g}\right)$ & 0.009255 \\
\hline
\end{tabular}

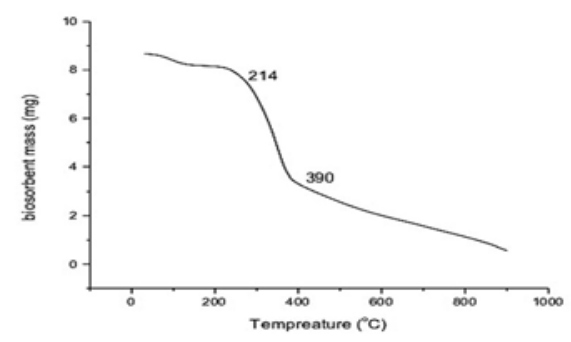

Figure 2: TGA spectra of the biosorbent.

$390^{\circ} \mathrm{C}$ a uniform deterioration of the organic matter was recorded to $900^{\circ} \mathrm{C}$. Similar thermal degradation profiles have been reported for maize tassels and vemicompost [2], [11], [22].

\subsection{Functional groups analysis of the biosorbent}

Fourier transform Infra-red spectroscopy was used to analyse the presence of some functional groups on the surface of the biosorbent (Fig. 3). These groups are the binding sites of the biosorbent with metallic species [22]. The peak observed at $3414 \mathrm{~cm}^{-1}$ is characteristic of the stretching vibrations of -N-H of primary and secondary amine and amide and -O-H of hydrogen bonded to phenols or alcohols [22]. The strong and sharp peak at $2919 \mathrm{~cm}^{-1}$ is due to $-\mathrm{C}-\mathrm{H}$ stretching vibration of aliphatic groups [23]. The peaks at $2154 \mathrm{~cm}^{-1}$ and $1739 \mathrm{~cm}^{-1}$ are due to $-\mathrm{C} \equiv \mathrm{C}$ - stretch of alkynes $[24]$ and $-\mathrm{C}=\mathrm{O}$ stretch of aldehydes and aliphatic esters, respectively [2]. The peaks observed at $614 \mathrm{~cm}^{-1}$ and $1626 \mathrm{~cm}^{-1}$ can both be attributed to bending vibrations of alkynes $(-\mathrm{C} \equiv \mathrm{C}-\mathrm{H})[24]$ and primary amines $(-\mathrm{N}-\mathrm{H})$ [21]. The peaks observed at $1502 \mathrm{~cm}^{-1}, 1446 \mathrm{~cm}^{-1}$, are due to $-\mathrm{C}=\mathrm{C}$ stretch of an aromatic compound [25], while $1266 \mathrm{~cm}^{-1}$ and $1064 \mathrm{~cm}^{-1}$ can be assigned to $-\mathrm{C}-\mathrm{N}$ stretch of aromatic amines [26] and -C-O stretch of alcohols, carboxylic acids and esters [21]. The presence of acidic functional groups has been implicated as the basis for metal uptake [27].

\subsection{Effects of varying of operating parameters}

Fig. 4 shows the effect of changes in $\mathrm{pH}$ values on the biosorption of $\mathrm{Pb}^{2+}$. The $\mathrm{pH}$ of a solution is a very important operating parameter because it affects metal-biosorbent interaction, solubility of metal ions and the charge of the functional groups of the biosorbent [11], [25]. In this study, the $\mathrm{pH}$ was varied from 2-12. There was an inverse relationship 


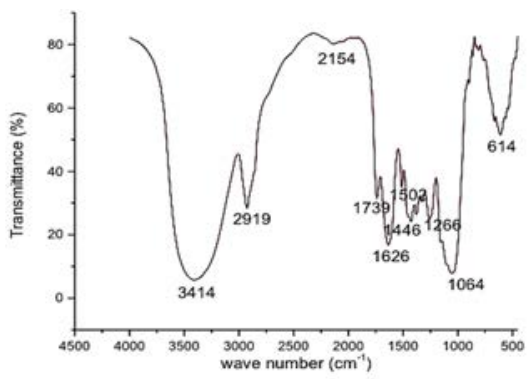

Figure 3: FT-IR Spectra of the biosorbent.

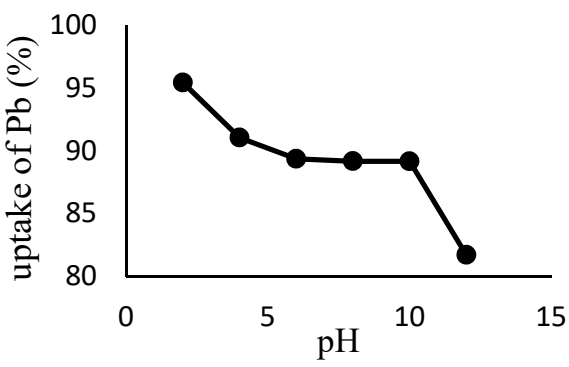

Figure 4: Variation of the uptake of $\mathrm{Pb}$ (II) ion with change in $\mathrm{pH}$ value (initial concentration $=10.7 \mathrm{mg} / \mathrm{L}$, contact time $=60 \mathrm{mins}, \mathrm{T}=298 \mathrm{~K}$, shaking speed $=250 \mathrm{rpm}$, biosorbent dosage $=1.0 \mathrm{~g}$ ).

between $\mathrm{pH}$ and uptake efficiency i.e. as the $\mathrm{pH}$ increased the biosorbent ability to remove $\mathrm{Pb}$ (II) from aqueous solution decreased. Acidic $\mathrm{pH}$ is suitable for the biosorption of $\mathrm{Pb}$ (II) ions as the likelihood of precipitation is not expected. $\mathrm{pH}$ values above 4 could cause lead(II) ions to precipitate out of solution as insoluble particle. The $\mathrm{pH}$ value of 2 was chosen as the optimum $\mathrm{pH}$ for this study and further experiments were conducted at this $\mathrm{pH}$ value. Gupta et al. [28] reported similar optimum $\mathrm{pH}$ of 2 in the biosorption of chromium(VI) from aqueous solutions by green algae spirogyra species. Azouaoau et al. [29] also reported an optimum $\mathrm{pH}$ value in the range of 3-4.6 for the adsorption of $\mathrm{Pb}$ (II) from aqueous solution unto untreated orange barks. An inverse trend was, however, observed for the removal of $\mathrm{Pb}$ (II) from aqueous solution using activated carbon from waste biomass [30].

From Fig. 5, the biosorption capacity increased and reached equilibrium at 45 minutes. Initially there was a rapid uptake of $\mathrm{Pb}^{2+}$ within the first 5 minutes removing up to $95 \%$ of $\mathrm{Pb}$ (II) ion from a $10.7 \mathrm{mg} / \mathrm{L}$ initial concentration. This could be due to the availability of binding sites on the surface of the biosorbent. There was a slow additional uptake of the metal ion after 5 minutes up to 45 minutes accounting for $96.78 \% \mathrm{~Pb}$ removal. Afterwards, there was a slight decrease in the biosorption process, which subsequently led to a plateau indicating that equilibrium had been achieved. Patnukao et al. [31] and Ugwekar and Lakhawat [32] reported 45 minutes as the optimum time for the adsorption of $\mathrm{Cu}^{2+}$ and $\mathrm{Pb}^{2+}$ and heavy metals on activated carbon from Eucalyptus camaldulensis dehn. bark and peanut shells, respectively. Oluyemi et al. [33] also reported an optimum time of 45 and 50 minutes for the adsorption of $\mathrm{Cd}^{2+}$ and $\mathrm{Pb}^{2+}$ from wastewater using palm kernel shell charcoal.

There was a steady increase in the uptake of $\mathrm{Pb}^{2+}$ as the biosorbent dosage increased until equilibrium was established (Fig. 6) [17]. Initially, there was an increase in $\mathrm{Pb}$ (II) uptake from $7.6 \%$ to $30.24 \%$ when the dosage was increased from $0.05 \mathrm{~g}$ to $0.1 \mathrm{~g} .91 .97 \% \mathrm{~Pb}$ (II) removal was observed when $1.0 \mathrm{~g}$ of the biosorbent was used. This was due to increase in surface area and binding sites for the attachment of the metal ion. But when $2.0 \mathrm{~g}$ of the biosorbent was used, there was a slight decrease to 91.67, showing that the biosorbent was saturated at this point. This could be due to the overlapping of the adsorption sites as dosage increased [17], [20]. 


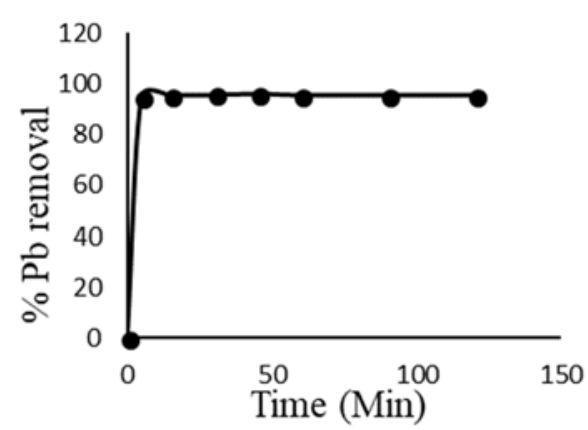

Figure 5: Variation of the uptake of $\mathrm{Pb}(\mathrm{II})$ ion with contact time (initial concentration $=10.7$ $\mathrm{mg} / \mathrm{L}, \mathrm{T}=298 \mathrm{~K}, \mathrm{pH}=2$, shaking speed $=250 \mathrm{rpm}$, biosorbent dosage $=1.0 \mathrm{~g}$ ).

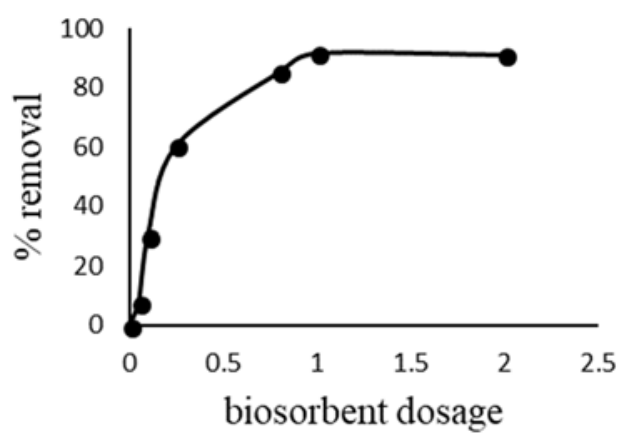

Figure 6: Variation of the uptake of $\mathrm{Pb}(\mathrm{II})$ ion with biosorbent dosage (initial concentration $=10.7$ $\mathrm{mg} / \mathrm{L}$, contact time $=60$ minutes, $\mathrm{T}=298 \mathrm{~K}, \mathrm{pH}=2$, shaking speed $=250 \mathrm{rpm})$.

\subsection{Biosorption isotherms and kinetics}

\subsubsection{Biosorption isotherms}

The experimental data obtained were analysed using the Langmuir and Freundlich adsorption isotherms. The linearised form of the models can be represented by eqns (4) and (5), respectively [34]-[36].

$$
\frac{1}{q_{e}}=\frac{1}{q_{\max }}+\left(\frac{1}{b q_{\max }}\right) \frac{1}{C_{e}},
$$

where $C_{e}$ is the equilibrium concentration of the metal ion $(\mathrm{mg} / \mathrm{L}), \mathrm{q}_{\mathrm{e}}$ is the quantity of $\mathrm{Pb}(\mathrm{II})$ ion adsorbed $(\mathrm{mg} / \mathrm{g}), q_{m}=q_{e}$ for a complete monolayer $(\mathrm{mg} / \mathrm{g})$ and $\mathrm{b}$ is the adsorption equilibrium constant $(\mathrm{L} / \mathrm{mg})$ [17].

$$
\log q_{e}=\log K_{f}+\frac{1}{n} \log C_{e},
$$

where $K_{f}$ is the adsorption capacity $(\mathrm{mg} / \mathrm{g})(\mathrm{L} / \mathrm{mg})^{(1 / \mathrm{n})}$ and $1 / \mathrm{n}$ is the intensity of the adsorption showing the heterogeniety of the adsorbent site and the energy of distribution [17], [36].

A linear graph was obtained by plotting $1 / q_{e}$ against $1 / C_{e}$ (Fig. 7 ) and $1 / q_{\max }$ was the intercept with $1 / b q_{\max }$ as the slope. A regression coefficient of 0.98 was obtained suggesting that the adsorption conforms to Langmuir model. The equilibrium data were also fitted to the Freundlich isotherm model by plotting $\log q_{e}$ against $\log C_{e}$ (Fig. 8). A linear graph was obtained with a regression coefficient of 0.99 which is higher than that obtained from the Langmuir model.

Based on the correlation coefficients obtained, the Freundlich model was the most suitable to describe the adsorption process and it suggests that adsorption of $\mathrm{Pb}^{2+}$ onto Mucilaginous stem of DEP is through a weak intermolecular Van der Waal forces and hence a physisorption process. 


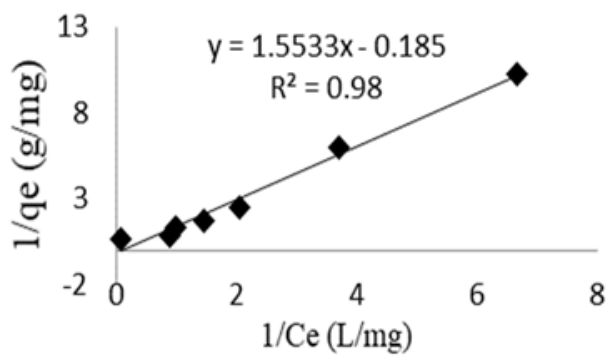

Figure 7: Langmuir plot for $\mathrm{Pb}^{2+}$ biosorption onto the stem of DEP.

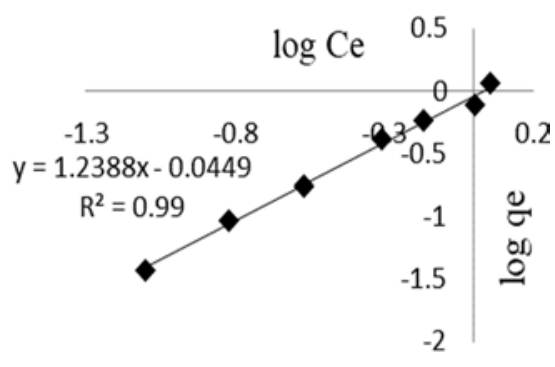

Figure 8: Freundlich plot for $\mathrm{Pb}^{2+}$ biosorption onto the stem of DEP.

\subsubsection{Kinetic models}

The pseudo first and pseudo second order kinetics equations were used to analyse the experimental data obtained from the influence of contact time on the biosorption of $\mathrm{Pb}^{2+}$ onto the powdered stem of DEP. The linearised equations for the pseudo first order and pseudo second order kinetics are presented in eqns (6) and (7), respectively [37], [38].

$$
\begin{gathered}
\log \left(q_{e}-q_{t}\right)=\log q_{e}-\left(\frac{k_{1} t}{2.303}\right) \\
\frac{t}{q_{t}}=\left(\frac{1}{k_{2} q_{e}^{2}}\right)=\frac{t}{q_{e}},
\end{gathered}
$$

where $q_{e}$ and $q_{t}$ are the amounts of $\mathrm{Pb}^{2+}$ adsorbed at equilibrium and at given time $t ; k_{1}$ and $k_{2}$ are the rate constants of pseudo first and pseudo second order models.

The pseudo first order plot as shown in Fig. 9 gave a poor plot with a regression coefficient of 0.02 . This was not suitable to explain the kinetics of the reaction. Fig. 10 shows the graphical representation of the pseudo second order plot, which yielded a very good plot with regression coefficient of 1.0. The pseudo second order kinetics best described the kinetics of the reaction. The constants obtained from the plots are presented in Table 3.

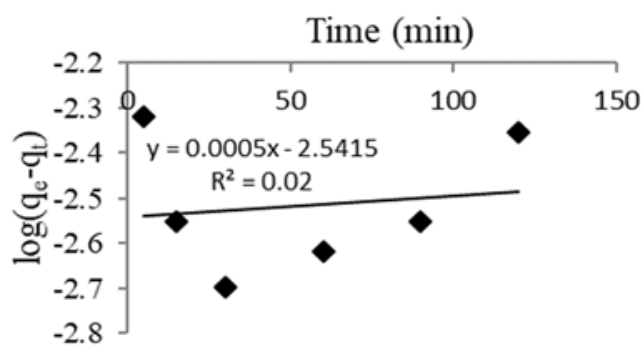

Figure 9: Pseudo first order kinetics for lead(II) ion biosorption onto the leaves of DEP.

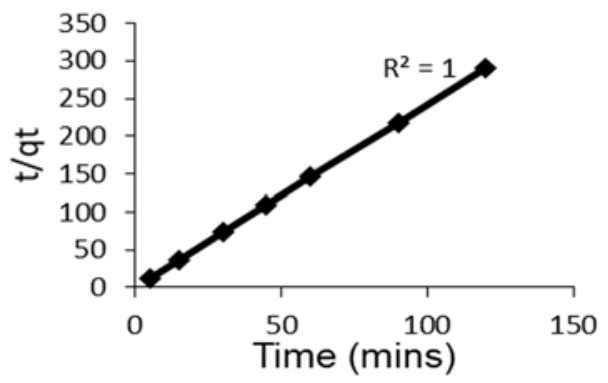

Figure 10: Pseudo second order kinetics for lead(II) ion biosorption onto the leaves of DEP. 
Table 3: Kinetic parameters for the biosorption of $\mathrm{Pb}$ (II) ion onto powdered stem of DEP.

\begin{tabular}{lll}
\hline Kinetic model & Parameter & Value \\
\hline Psuedo-first order & $\mathrm{q}_{\mathrm{e}}(\mathrm{mg} / \mathrm{g})$ & $2.87 \times 10^{-3}$ \\
& $\mathrm{~K}_{1}\left(\mathrm{~min}^{-1}\right)$ & $-1.15 \times 10^{-3}$ \\
& $\mathrm{R}$ & 0.0199 \\
Pseudo-second order & $\mathrm{q}_{\mathrm{e}}(\mathrm{mg} / \mathrm{g})$ & 0.640 \\
& $\mathrm{~K}_{2}(\mathrm{~g} / \mathrm{mg} / \mathrm{min})$ & 31.610 \\
& $\mathrm{R}$ & 1.000 \\
\hline
\end{tabular}

\section{CONCLUSION}

Powdered biomass of a renewable low-cost adsorbent (stem of DEP) was characterised and its potential was explored for heavy metals uptake from aqueous solution. The adsorbent has more affinity for $\mathrm{Pb}$ (II) when compared to the other metals and the uptake affinity followed the trend: $\mathrm{Pb}(\mathrm{II})>\mathrm{Cr}(\mathrm{VI})>\mathrm{Cu}(\mathrm{II})$. Further investigation on the adsorption of $\mathrm{Pb}$ (II) showed an initial rapid uptake by the adsorbent which decreases while approaching equilibrium. The experimental data fitted well into the Langmuir and Freundlich adsorption isotherms but the Freundlich isotherm model best describes the adsorption process while the pseudo-second order kinetics best described the kinetics of the reaction.

\section{ACKNOWLEDGEMENT}

This study was funded by the Research and Publications committee (RPC) of the University of Venda.

\section{REFERENCES}

[1] Edokpayi, J.N., Odiyo, J.O. \& Olasoji, S.O., Assessment of heavy metal contamination of Dzindi river, in Limpopo Province, South Africa. International Journal of Natural and Scientific Research, 2, pp. 185-194, 2014.

[2] Olorundare, O.F., Msagati, T.A.M., Krause, R.W.M., Okonkwo, J.O. \& Mamba. B.B., Steam activation, characterization and adsorption studies of activated carbon from maize tassels. Chemistry and Ecology, pp. 1-18, 2014.

[3] Tarr, J.A., The search for the ultimate sink: urban pollution in historical perspective, University of Akron Press, 1996.

[4] Lohmann, R., Jurado, E., Michael, E., Pilson, Q. \& Dachs, J., Oceanic deep-water formation as a sink of persistent organic pollutants. Geophysical Research Letters, 33, pp. 1-4, 2006.

[5] Yu, J.G., Zhao, X.H., Yu, L.Y., Jiao, F.P., Jiang, J.H. \& Chen, X.Q., Removal, recovery and enrichment of metals from aqueous solutions using carbon nanotubes. Journal of Radioanalytical and Nuclear Chemistry, 299, pp. 1155-1163, 2014.

[6] Hernandez-Montoya, V., Perez-Cruz, M.A., Mendoza-Casillo, D.I., Moreno-Virgen, M.R. \& Bonilla-Petriciolet, A., Competitive adsorption of dyes and heavy metals on zeolitic structure. Journal of Environmental Management, 116, pp. 213-221. 2013.

[7] Nriagu, J.O., A silient epidermic of environmental poisoning. Environmental Pollution, 50, pp. 139-161, 1988.

[8] Nriagu, J.O., Toxic metal pollution in Africa. Science of the Total Environment, 121, pp. 1-37, 1992. 
[9] Sun, G., Arsenic contamination and arsenicosis in China. Toxicology and Applied Pharmacology, 198, pp. 268-271, 2004.

[10] BBC, Nigeria lead poisoning death doubles. www.bbc.co.uk/news/world-Africa11478986. Accessed on: 26 Jun. 2014.

[11] Mwangi, I.W., Ngila, J.C. \& Okonkwo, J.O., A comparative study of modified and unmodified maize tassels for removal of selected trace metals in contaminated water. Toxicology and Environmental Chemistry, 94(1), pp. 20-39, 2011.

[12] Mihajlovic, M.T., Lazarevic, S.S., Jankovic-Castvan, I.M., Kovac, J., Jokic, B.M., Janackovic, D.T. \& Petrovic, R.D., Kinetics, thermodynamics, and structural investigations on the removal of $\mathrm{Pb}^{2+}, \mathrm{Cd}^{2+}$, and $\mathrm{Zn}^{2+}$ from multicomponent solutions onto natural and $\mathrm{Fe}(\mathrm{III})$-modified zeolites. Clean Technology and Environmental Policy, 14, pp. 407-419, 2015.

[13] EPA, Toxicity and priority pollutants. http://water.epa-gov/scitech/methods/cwa/ pollutants-background.cfm. Accessed on: 26 Jun. 2016.

[14] Ahmad, R., Kumar, R. \& Laskar, M.A., Adsorptive removal of $\mathrm{Pb}^{2+}$ form aqueous solution by macrocyclic calyx[4]naphthalene: kinetic, thermodynamic, and isotherm analysis. Environmental Science and Pollution Research, 20, pp. 219-226, 2013.

[15] Botha, R., Dicerocaryum eriocarpum. http://ecoport.org/ep?Plant=18027\& entityType. Accessed on: 29 Jun. 2015.

[16] Fern, K., Dicerocaryum eriocarpum - useful tropical plants. http://tropical.the ferns.info/viewtropical.php? id. Accessed on: 29 Jun. 2015.

[17] Edokpayi, J.N., Odiyo, J.O., Msagati, T.A.M. \& Popoola, E.O., Novel approach for the removal of lead(II) ion from wastewater using mucilaginous leaves of Diceriocaryum eriocarpun plant. Sustainability, 7, pp. 14026-14041, 2015.

[18] Moyo, M. \& Chikazaza, L., Bioremediation of lead (II) from polluted wastewaters employing sulphuric acid treated maize tassel biomass. America Journal of Analytical Chemistry, 4, pp. 689-695, 2013.

[19] Zvinowanda, C.M., Okonkwo, J.O., Agyei, N.M. \& Shabalala, P.N., Physicochemical characterization of maize tassel as an adsorbent. I. surface texture, microstructure and thermal stability. Journal of Applied Polymer Science, 111, pp. 1923-1930, 2009.

[20] Rodrigues, L.A., Ribeiro, L.A.D., Thim, G.P., Ferreira, R.R., Alvarez-Mendez, M.O. \& Coutinho, A.D., Activated carbon derived from macadamia nut shells: an effective adsorbent for phenol removal. Journal of Porous Materials, 20, pp. 619-627, 2013.

[21] Elizalde-Gonzalez, M.P., Mattusch, J., Pelaez-Cid, A.A. \& Wennrich, R., Characterization of adsorbent materials prepared from avocado kernel seeds: Natural, activated and carbonized forms. Journal of Analytical and Applied Pyrolysis, 78, pp. 185-193, 2007.

[22] Pereira, M.G. \& Arruda, M.A.Z., Vemicompost as a natural adsorbent material: characterization and potentialities for cadmium adsorption. Journal of Brazilian Chemical Society, 14(1), pp. 39-47, 2003.

[23] Wang, J. \& Chen, C., Biosorbents for heavy metals removal and their future. Biotechnology Advances, 27, pp. 195-226, 2009.

[24] Prasad, S.G., De, A. \& De U., Structural and optical investigations of radiation damage in transparent PET polymer films. International Journal of Spectroscopy, pp. 1-7, 2011.

[25] Olorundare, O.F., Krause, R.W.M., Okonkwo, J.O. \& Mamba, B.B., Potential application of activated carbon from maize tassel for the removal of heavy metals in water. Physics and Chemistry of the Earth, 50, 52, pp. 104-110, 2012. 
[26] Kacurakova, M., Ebringerova, A., Hirsch, J. \& Hromadkova, Z., Infrared study of arabinoxylans. Journal of the Science of Food and Agriculture, 66, pp. 423-427, 1994.

[27] Gilbert, A., Emmanuel, I., Adebanjo, A. \& Olalere, G., Biosorptive removal of $\mathrm{Pb}^{2+}$ and $\mathrm{Cd}^{2+}$ onto novel biosorbent: defatted Carica papaya seeds. Biomass Bioenergy, $\mathbf{3 5}$, pp. 2517-2525, 2011.

[28] Gupta, V.K., Shrivastava, A.K. \& Jain, N., Biosorption of chromium (VI) from aqueous solutions by green algae spirogyra species. Water Resources, 35, pp. 40794090, 2001.

[29] Azouaoua, N., Belmedanib, M., Mokaddema, H. \& Sadaoui, Z., Adsorption of lead from aqueous solution onto untreated orange barks. Chemical Engineering Transaction, 32, pp. 55-60, 2013.

[30] Erdem, M., Ucar, S., Karagöz, S. \& Tay, T., Removal of lead (II) Ions from aqueous solutions onto activated carbon derived from waste biomass. The Scientific World Journal, pp. 1-7, 2013.

[31] Patnukao, P., Kongsuwan, A. \& Pavasant, P., Batch studies of adsorption of copper and lead on activated carbon from Eucalyptus camaldulensis dehn. bark. Journal of Environmental Science, 20, pp. 1028-1034, 2008.

[32] Ugwekar, R.P. \& Lakhawat, G.P., Recovery of heavy metal by adsorption using peanut hull. International Journal of Advanced Engineering Technology, 3, pp. 39-43, 2012.

[33] Oluyemi, E.A., Adeyemi, A.F. \& Olabanj, I.O., Removal of $\mathrm{Pb}^{2+}$ and $\mathrm{Cd}^{2+}$ ions from wastewaters using palm kernel shell charcoal. Research Journal of Applied Sciences, Engineering and Technology, 1, pp. 308-313, 2012.

[34] Langmuir, I., The constitution and fundamental properties of solids and liquids. Journal of American Chemical Society, 38, pp. 2221-2295, 1916.

[35] Freundlich, H.M.F., Uber die adsorption in losungen. Zeitschrift für Physikalische Chemie, 57, pp. 385-470, 1906.

[36] Hameed, B.H., Mahmoud, D.K. \& Ahmad, A.L., Sorption of basic dye from aqueous solution by pomelo (Citrus grandis) peel in a batch system. Colloids and Surfaces: A Physicochemical and Engineering Aspects, 316, pp. 78-84, 2008.

[37] Lagergren, S., Zur theorie der sogenannten adsorption gelö ster stoffe (About the theory of so-called adsorption of soluble substances). K. Sven. Vetenskapsakademiens. Handlingar, 24, pp. 1-39, 1898.

[38] Ho, Y.S., Wase, D.A.J. \& Forster, C.F., Kinetic studies of competitive heavy metal adsorption by Sphagnum moss peat. Environmental Technology, 17, pp. 71-77, 1996. 